\title{
The Impact of Bank Credits on the Manufacturing Sector in Nigeria (1980-2015)
}

\author{
Otubu, Osaretin Paul \\ Master $(\mathrm{Mr})$ \\ University of Port Harcourt, Centre for Research Management and Development, P. M.B 5323, Choba, Port \\ Harcourt, Rivers State, Nigeria
}

\begin{abstract}
The study examined the impact of bank credits on the manufacturing sector in Nigeria from 1980 to 2015. The broad objective of the study is to examine the impact of bank credits on the manufacturing sector in Nigeria between 1980 and 2015. The econometrics methods of ordinary least squares, co-integration, error correction model and granger causality test were used as the main analytical tools. From the estimated error correction model, we found that bank credits to the manufacturing sector had a positive impact on the manufacturing sector output. Government expenditure, gross capital formation and tertiary school enrolment conforms to apriori expectation. A bank credit was found to be necessary for influencing or boosting manufacturing sector output. In addition, the granger causality result reveals that there is causal relationship between bank credits and manufacturing sector output in Nigeria. It is therefore recommended that the cost of borrowing should be reduced, and relevant authorities should maintain a sustained effort aimed at making sure that banks strictly comply with the credit concession granted to the manufacturing sector, and the government should provide social amenities and conducive environment for industrialization.
\end{abstract}

Key Words: Bank credits, manufacturing, sector, loans, and advances

\subsection{INTRODUCTION}

Availability of funds is a key dynamic on which productivity relies on. The actions of most fiscal organizations and institutions especially deposit banks and other advancement banks ascertain the financial and monetary ontogeny, as well as retardation or advancement of any system. The banks are common for the stage in performing of fiscal/monetary mediation, which involves transferring finances from the surplus financial unit to the insufficient unit of a country

The operation of financial institution credits in the ontogeny of a system can be admitted because of the information that much economic units utilize it to get their targets. Adeniyi (2006) said authorities make use of loans/advances from financial institutions to fulfil various kinds of recurrent and capital expenses, while firms and households make use of loans/advances to get products. Ademu (2006) opined that bank loans/advances be utilized to avert moneyspinning actions from an ample pack-up in the occurrence of raw disasters, like drought, flood, or disease. The financial institutions is at the heart of credit accession by mobilizing extra finances from savers that do not have urgent usage of such money and consequently groove it to credit to capable entrepreneurs or investors that possesses good venture know-how on how to make more wealth in the system but fall short of the money to form such wealth.

From figures in Nigeria, deposit institutions' outstanding loans and advances to export, solid minerals, agriculture and manufacturing in 2007 was at $10.2 \%, 3.1 \%, 10.1 \%$ and $1.4 \%$ correspondingly (CBN, 2013).

In ensuring that loans/advances are accessible to the real sectors, banks have therefore promoted a medium which will lead to increase in productive activities in an economy (Adekanye, 1986). Consequently, widening development of funds for investment; hence, living standard improvement. 
International Journal of Science and Management Studies (IJSMS)

Volume: 2 Issue: 4
July to August 2019
E-ISSN: 2581-5946

www.ijsmsjournal.org

Tawose (2012) opined that the speedy growth and advancement of productive activities has raised the need for loans/advances by companies and firms. He pierce out that financial institutions like deposit banks and advancement financial institutions have gradually been giving loans/advances for productivity, most of which are managed and controlled by increasing indigenous enterprisers. To ensure credit mobility to the real sector, the government and the Apex bank of Nigeria constituted Micro/Medium Ventures Equity Financing/Investment Scheme in 2001, Interest Draw-bank Scheme in 2003 etc. It was aimed at moving loans/advances to the real sector of the economy to help the sectors have output increment, performance and productivity increment, and growth and advancement boosting in the economy (Nwankwo, 2013, Tawose, 2012, and CBN, 2009). This is the base that necessitated the research to evaluate the influence of credits on the manufacturing sector in the country Nigeria.

The achievement of ontogeny targets also relies on the volume of investments/funding on the manufacturing sector (Job 2002). That is to roughly say that investment/capital formation is obligatory for the attainment of development. Asset/capital formation will promote the manufacturing sector yield.

Becker (2008) stressed that training, health and education are essential investment in human resources. The government/authorities spending on education is necessary for labour performance, which is human development that will enhance manufacturing sector outcomes/outputs.

\subsection{Statement of Problem}

For the ontogeny and development of any economy, loans/advances are needed tools that may possibly be of good quality financial aid. Growth is increased when credits are accessible to the real sector - manufacturing. Therefore, ontogeny and advancement will be adversely affected if loans/advances are not accessible to the productive sectors.

Despite the investment and resources control by the Apex bank of Nigeria, which is targeted at promoting growth in the real sectors, manufacturing have experience difficulty in accessing loans/advances (Akinleye, Akanni and Oladoja, 2003). Credits set-backs or pretermit of the manufacturing sector has resulted increase in unemployment, inferior production increase, capacity usage decrease, modern machineries investment inability, information and technology investment inability, human development inability etc. Ebi (2014) opined that hopeless contact to credits by the productive sector increases the amount of impoverished in the system and as such they grasp knotty in crimes. Other issues are slums increase, houses demand decrease, homeless individuals increase etc. are in addition caused by indigent and derisory accession to loans/advances and poor regime/government spending.

CBN document in 2010 displayed that loans/advances to manufacturing sector increased from N427.28billion in year 2006 to N1, 109.86billion in year 2009. Ogar, Nkamare \& Effiong (2014) said that loans/advances to manufacturing as a fraction to entire banking loans/advances is around 15.7\% from 1990 to 1994, and $25.8 \%$ from 1995 to 2000. Despite these increases in loans/advances to the manufacturing sector, productivity and performance continued to be low, which customarily affect the performance of the manufacturing sector and thus affect the GDP.

It is against this setting that this study quest to discover answers to the following: To what extent can performance of the manufacturing sector output be affected by credits? Is there causality relationship between manufacturing sector output/yield and bank loans/advances?

\subsection{Objectives of the Study}

The major aim of this research is to evaluate the effect of bank credits on the appraisal of the manufacturing sector in Nigeria. The specific objectives of the research are:

(i) To examine the extent of the impact of bank credits/loans on the manufacturing sector in Nigeria; 
(ii) To investigate the causality relationship between bank credits/loans and manufacturing sector output/yield.

\subsection{Research Hypothesis}

i. $\mathrm{HO}_{1}$ :Bank credits/loans has no significant influence on manufacturing sector output/yield;

ii. $\mathrm{HO}_{2}$ :There is no causal relationship between bank credits/loans and manufacturing sector output/yield.

\subsection{Significance of the Study}

The research will impart to the existing structure of noesis on issues pertaining loans/advances and accomplishment on the manufacturing sector. The discovery from this study will be of serious importance to manufacturers/producers, financial organizations, government authorities as well as the general public.

\subsection{Theoretical Literature}

\subsection{LITERATURE REVIEW}

Anyanwu (2010) explained credits as a fiscal facility given to an individual, company or government for urgent usage but with an anticipated payment at an agreed future time. Aryeetey (1996) defined bank credit as the sum total given out with a forthcoming future date of repayment. The Nigerian Deposit Insurance Company prudential procedure of 1990 however, gave a broad meaning of credit, and this take account of a mass of every loans, overdraft, advances, infomercial papers, bills discount, bankers acceptance, lease and warrantees. According to Mishra, Das \& Pradhan (2009), credit is the aggregate amount of finance supplied by banks to individuals, organizations and government for investment and consumption reasons. That is, credit is acknowledge as resources provision like loan provision by the lender/creditor to the borrower/debtor, if the debtor/borrower do not repay the creditor on time, in so doing generated a debt, and as an alternative arranges to reimburse or give back those credits at a future time. Nwaeze and Ujah (2007) opined that credit is a fiscal assistance or facility given to corporate or individual client by a financial organization for particular reason, time frame and particular interest rate. It helps a country to achieve its developmental aims and targets.

However, financial institutions have merits over credits alternative source. It is because commercial banks have good knowledge than other credits givers which is because of economies of scale and information comparative advantage assemblage. Due to their information and cost upper-hand, commercial banks can give good terms of contract to organizations than any other financing sources and banks come up with improved in a row than other position suppliers ensuing (Rajan and Zingales 1998). Firms utilizing just domestic sources of funding, however, may be expected to get lesser return rates on this finance source in comparison to those making use of external sources. Firms do business beyond their funds due to credits (Villalpando, 2015). Mishra, Das \& Pradhan (2009) said that individuals take in credit for investment and consumption reasons, organization acquire credits to invest in machinery and plant and government acquire credits/loans to expend on recurrent and capital things. Financial institution loans help in bringing forth self-employment, business enjoying economic of scale and prevent total economic collapse in case of disaster (Nwanyanwu, 2011).

Ijere (1998) opined that credit could be seen as an integer that complements other production factors and makes under-utilized capabilities working for productivity increment. Credit is seen as a vital thing to growth most especially in less developed nations as it oiled the economy. Hence, the credit role in growth has been acknowledged by researchers as divers agents in the economy can invest in different opportunities (Timsina, 2014). Bencivenga and Smith (1991) said that goods for consumption in the nation are manufactured from capital and labour. An enterpriser, who obtains loans from commercial bank to fund his or her venture, utilizes it to engage labour in order 
International Journal of Science and Management Studies (IJSMS)

Volume: 2 Issue: 4
July to August 2019
E-ISSN: 2581-5946

www.ijsmsjournal.org

to manufacture products. Research from Odedokun (1998), Boyreau-Debray (2003), Beck \& Levine (2002), and queen \& Levine (1993) exposed a damaging correlation between credit debt and growth because the Chinese banks were sending funds into the diminishing sections of the Chinese State Venture, and consequently, the system did not promote ontogeny and advancement. Also, Beck, Levine and Loayza (2000) noticed that credit is a good growth predictor and research by Crowley (2008) supported this perspective. Things included are production factors, aggregate productivity from factors like technological change named the Schumpeterian formulation, human capital, real capita GDP etc. (Allen and Ndikumama, 1998; Odedokun, 1998; king and Levine, 1993).

Rajan and Zingales (1998) puts a good perspective in the examination about growth and financial market. They discovered that industries needing external funding grew quicker in nations with financial market that is developed. They made used of U.S. company level data/information to evaluate the external funding reliance of divers producing sector. Their canonic presumption is that financial/fiscal markets are considerably developed in U.S., so the companies can borrow at the amount desired, which is ascertained only by the firm's demand for external funding. Their opinion suggested that markets noted with less competitive and concentrated banks are not developing at their potency, since companies do not have accession to loans, the lack results to less growth or ontogeny. Villalpando (2015) was of the opinion that loan is insufficient ingredient to promote company's productivity. He said that companies may have accession to loans but if they do not have viable investment opportunities will use borrowed money for less viable investment, like funding of daily operation/role, or not requesting for investment credits. This view is in consonant Ijeres (1998) opinion. Hence, accession to loans without proper investment opportunity could result to less efficiency in terms of growth. The path of transmission from loans to productivity is its effectiveness other than its volume/amount (De Gregorio and Guidotti, 1995). Financial institution loans will have important effect on firm's productivity with the right investment paradigm.

Given the deteriorating fiscal situation in less developed nations, particularly in terms or poor revenue and poor savings, international and national bodies have started divers policies meshed to boost the provision of real sector loans (Olowa and Olowa, 2011). The government in Nigeria and its divers agencies did acknowledge the significance of the real sector and decided to start organizations and programmes via its divers policies that support accession to basic amenities and finance for production, with the idea of achieving developmental targets. In Nigeria, to puzzle out the problem of producing funding so as to promote manufacturing, the government of Nigeria gave priority to the manufacturing and agrarian sector by instructing banks via CBN to allocate a certain percent of their finance for loan to agrarian and manufacturing sphere (Toby \& Peterside, 2014 and Nwankwo, 2013). Thus, to make banks achieve their credit disbursement target. The outcome recorded by the producing sector in early 1970s to early 1980s, may partly be ascribed to favorable and expansionary policy regime. Well operational financial markets support accession of companies to new markets, and aid competition, productivity and innovation in the economy (Malik, Teal and Baptist, 2004). Therefore, the manufacturing sector give about $9.5 \%$ to GDP outgrowth and over 70\% capability operation in 1975 (Mike, 2010). Before the deregulation in 1986, rate of interest has been fixed by the Apex Bank of Nigeria via administrative fiat but with the target of moving loans to the preferred sectors. But the liberalization of the system and compulsory sectoral allotment abolition of credits/loans in year 1989, resulted to the interest rate being determined by the market which influenced the loans allotment to the preferred sector. Over the years the government have made budgetary allotments to the real sectors of which in comparison with the aggregate budget, did not meet policy intents (Eze, Ugochukwu, Awulonu, Lemehi and Okon, 2010). The progress in institutions, programs, and schemes one anticipated important productive sector outcome/output increase overtime. Inspite all these, the GDP index of the real sector shows total substantial growth absence. 


\section{The Loanable finance Theory}

The neo-classical framework or loanable finance concept was formulated by Wicksell, but later publicized and modified by Robertson. The concept affirmed that interaction of demand and supply of such funds ascertains the interest rate. That is, interest rate is affirmed by the demand and supply interaction of loanable funds. This supposition is a betterment of the interest rate classical theory, in that the loanable finance supply is wider in scope, and also contains not only savings from current income but bank loans as well. The framework hypothesizes that financial institution loans and dis-investment are important finances, which are available when the recipients pays interest. Also, financial institution loans can become obtainable for investment purposes. Dis-invested resources are source of finance that borrowers can obtain also. Financial institution loans are presumed to be invested in projects that are viable, and enhance real sectoral performance which should stimulate the economy.

\section{The New Growth Theory}

This philosophy was formulated by Romer (1986), Lucas (1987) \& Rebelo (1991). The concept says that policy actions have influence on the economy's future growth rate. Jhingan (2006), opined that new growth formulation says that advancement in technology is the product of human capital, investment level and capital stock availability. Englama, Dodoko and Nnanna (2004), said that growth in finance can influence economic growth in three productive ways. Which are: increment of the efficiency and competence of financial intermediation, and bettering the marginal productivity of savings and capital rate. This depicts that banks can have good influence on the economy by performing its operation efficiently in mobilization of deposits and credits provision.

\section{Financial Intermediation Theory}

Financial institution loans plays serious role in fiscal intermediation which channel resources to units in the economy that make use of them for productive usage. The conceptual framework that initiates the relations between productive sector, fiscal intermediation and growth is enclosed in the research of Goldsmith (1969), Schumpeter (1934) \& Shaw (1973). Of which they showed the important roles financial mediation displays or executes in boosting economic growth and rapid development. Greenwood and Jovanorich (1990) opined that financial advancement enhance rapid growth and development of any nation. Bencivenga and Smith (1991) stated that the banking industry advancement in boosting financial mediation plays a pivotal role in the development of a nation by moving savings to serious productivity.

\section{Solow-Swan Growth Model}

Solow \& Swan (1956) present what later was seen as growth model for economics during the 1950s. This concept opined that there are decreasing returns to capital and labour. Capital from savings is gathered as output of workers decreases because of population increase and depreciation. The decreasing returns in capitalist economy may get to a situation where progress in technology and worker per capital will be constant and growth will discontinue. This stage is known as steady state. The proponent of the framework says that nations can conquer this level and continue to experience growth by making use of modern/new technology. Even on the long-run output of capital will rely on the savings level. Though output growth do not rely on savings level. The situation by which nations continue to experience growth despite the decreasing returns is exogenous which leads to new technology creation that allows production with resources that are available, and makes a nation to grow. The intriguing prediction of the concept is that developing nations can grow quicker and catch-up with developed nations if the nations operation on almost the same savings and technology level. 


\section{Schumpeterian Theory}

The theory was constituted by Joseph Schumpeter (1934). The concepts explicate growth as creative destruction and innovation which recognizes technological progress in producing different things. Hence, enterprisers create new products so as to control or govern the market and get more profits. By doing this, old products and technologies are consequently made obsolete.

\subsection{Empirical Literature}

Tawose (2012) evaluated the influence of credits on manufacturing performance in Nigeria (1975-2009) making use of co-integration and ECM technique. The outcome displayed that industrial/manufacturing sector have a long run relationship with banks' credits to the interest rate, industrial sector, inflation rate and aggregate saving. The research also showed that banks' credits to interest rate, industrial sector, inflation rate and aggregate saving have positive influence on real GDP manufacturing in the short-term while in the long-term banks' credits to industrial sphere have negative influence. It may be due to divers taxes levied against the manufacturing sector. Nwosa and Oseni (2013) investigated the influence of banks credits to SMEs on production/manufacturing output/yield in Nigeria (from 1992-2010) using ECM technique. The outcome revealed that banks credit to SMEs had unimportant influence on production outcome both in short and long term. The unimportant/insignificant outcome may be due to credit diversion to personal interest usage rather than for the SMEs purpose. The research therefore concluded that there is necessity for more conscious efforts and deliberation on the part of government in making sure that credit is given to the real users. Ajayi (2007) investigated the influence of bank loans on manufacturing performance/outcome in Nigeria (1975 - 2003). The outcome displayed that bank loans and inflation impacted negatively on manufacturing/production sphere. It means that rise in bank loans exerts negative performance on manufacturing sector. The negative influence may be due to interest rate being high and business environment being harsh within the period of this investigation.

Ogar, Nkamare and Effiong (2014) evaluated the impact of bank loans on manufacturing/production sector in Nigeria (1992 - 2011) utilizing OLS analysis. The outcome of the research revealed that bank loans have significant influence on the real sector. It is due to the divers credit policies which CBN initiated with the purpose of moving credits/loans to the real sectors of the economy and ensuring that there is effective usage of credits. They recommended/concluded that government should make sure that there is availability and sufficient loans allotment to the real sector in Nigeria with attractive or reasonable interest rate.

Ogujiuba, Ohuche and Adenuga (2004) examined the impact of loans availability to SMEs in Nigeria. The research made use of conceptual framework utilizing cross-sectional information or data to evaluate programs and schemes in Nigeria. Findings from the study showed that loans impacted SMEs significantly. Villalpando (2015) examined the influence of bank loans on Mexican company with data from ENAFIN. Making use of OLS technique. The research showed that significant influence from bank loans existed on company's output. The impact was bigger for the companies that have bank loans access and investment prospects than those companies that have just investment prospects or bank loans. The necessary parameters showed a positive influence of bank loans and consistency with estimation techniques.

Generally speaking bank loans enhances productive independence provided the company has investment prospects or opportunities. It is true if the enterprisers that collected the loans effectively make use of the credits. Nwanyanwu (2008) evaluated the impact of credits/loans and economic growth in Nigeria utilizing OLS. The outcome shows that, regardless of the amount of credits given, institutional credits were insignificant to growth in Nigeria. The insignificant influence may be due to credits diversion for personal use. Akujuobi and Chima (2012) investigated the influence of bank loans to the productive sector on development in Nigeria (1960-2008) using OLS method. Bank 
loans to each sub-sector involved in production was regressed against GDP. The outcome shows that there is a longrun relation between growth and credits/loans to the production sector. Chinweoke, Elizabeth and Egwu (2015) examined the influence of bank credits to manufacturing and agricultural sectors on growth in Nigeria (1994 - 2013) using OLS method. The outcome of the research revealed that bank credits to manufacturing and agricultural sectors have significant influence on growth. The study's outcome is in consonant to Anthony (2010) research work. It may be due to strict measures used by $\mathrm{CBN}$ in ensuring that loans given-out are effectively used within the study period. Toby and Peterside (2014) investigated the function of financial institution in manufacturing and agricultural sectors in Nigeria (1981-2010) utilizing inferential and descriptive methods. The descriptive method was utilized to get the standard deviations and mean for the comparative periods. Trend graphs were used also for the comparative intervals. The inferential involved two multiple regression utilizing OLS method. The findings showed significant relations between bank loans and manufacturing output.

\subsection{Evaluation of Literature Reviewed}

On the theoretical and empirical literature reviewed, this research extended the period of the research beyond the past research works reviewed that ended at 2012. This is due to change in policies and prevailing historical facts.

The lengthening of the period present the possibility to enchant these changes. The research work also concentrated on the influence of credits/loans on the manufacturing sector productivity in Nigeria. Like Ajayi (2007), Nwanyanwu and some others did not fully concentrate on bank loans/credits impact on the manufacturing sector.

\subsection{Research Design}

\subsection{METHOD OF STUDY}

Research draw-up plans according to Baridam (2012), is a framework that researchers employ as a funnel for collating and examining facts for a research work. The research design is about how the research work subjects can be imputed in the scope of the study and how it will be used in the study settings to get the necessary data. This research made use of quasi-experimental study draw-up plan. Hence, it is analytical. Making use of OLS technique, Co-integration, ECM and Granger causality. Trend graphs were also used.

\subsection{Model Specification}

The model made use of linear pattern. The dependent variable is manufacturing sector output (MSO). The independent variables are Bank Credits to Manufacturing (BCM), Government Expenditure (GEX), Gross Capital Formation (GCF) and Tertiary School Enrolment (TSE).

Manufacturing Sector Output (MSO): It is the contribution of the manufacturing sector to the GDP in Nigeria. The MSO is the nominal output.

Bank Credits to Manufacturing Sector (BCM): It is the aggregate loans/advances from banks given to enterprisers in the manufacturing sector so as to enhance the performance of the real sector. $\mathrm{BCM}$ is expected to have positive relationship with MSO

Government Expenditure (GEX): It is all the nominal expenditures (both capital and recurrent) of the government. It is the aggregate government spending on social overhead and infrastructure.

Gross Capital Formation (GCF): It is the nominal spending on assets like machineries, buildings etc.; which can be for replacing or increasing the stock of already existing assets/equity. It is part of the expenditure on GDP, and hence, revealed the amount of the new value added that is invested rather than being consumed. 
Tertiary School Enrolment (TSE): It is used as proxy for labour. This is the actual number of students officially registered and/or attending lecture in higher institutions.

Secondary data from CBN was employed for the research period.

\subsection{Analytical Framework}

The model/framework for the work is specified as:

$\mathrm{MSO}=\mathrm{f}(\mathrm{BCM}, \mathrm{GEX}, \mathrm{GCF}, \mathrm{TSE})$

Linear Specification: $M S O=a_{0}+a_{1} B C M+a_{2} G E X+a_{3} G C F+a_{4} T S E+U$.

The Apriori Expectation: $\mathrm{a}_{1} \square 0, \mathrm{a}_{2}>0, \mathrm{a}_{3}>0$, and $\mathrm{a}_{4}>0$

Method of Data Analysis: OLS, Augmented Dickey-Fuller, Unit root test, Co-integration, ECM and Granger Causality.

\subsection{DATA PRESENTATION}

The main objective of this research is to evaluate the influence of bank credit on the manufacturing sector output (1980 to 2015). See the trend of the variables in the figures below.

\subsection{Trend Analysis}

Fig.1 Manufacturing Sector Output \& Bank Credit/Loan

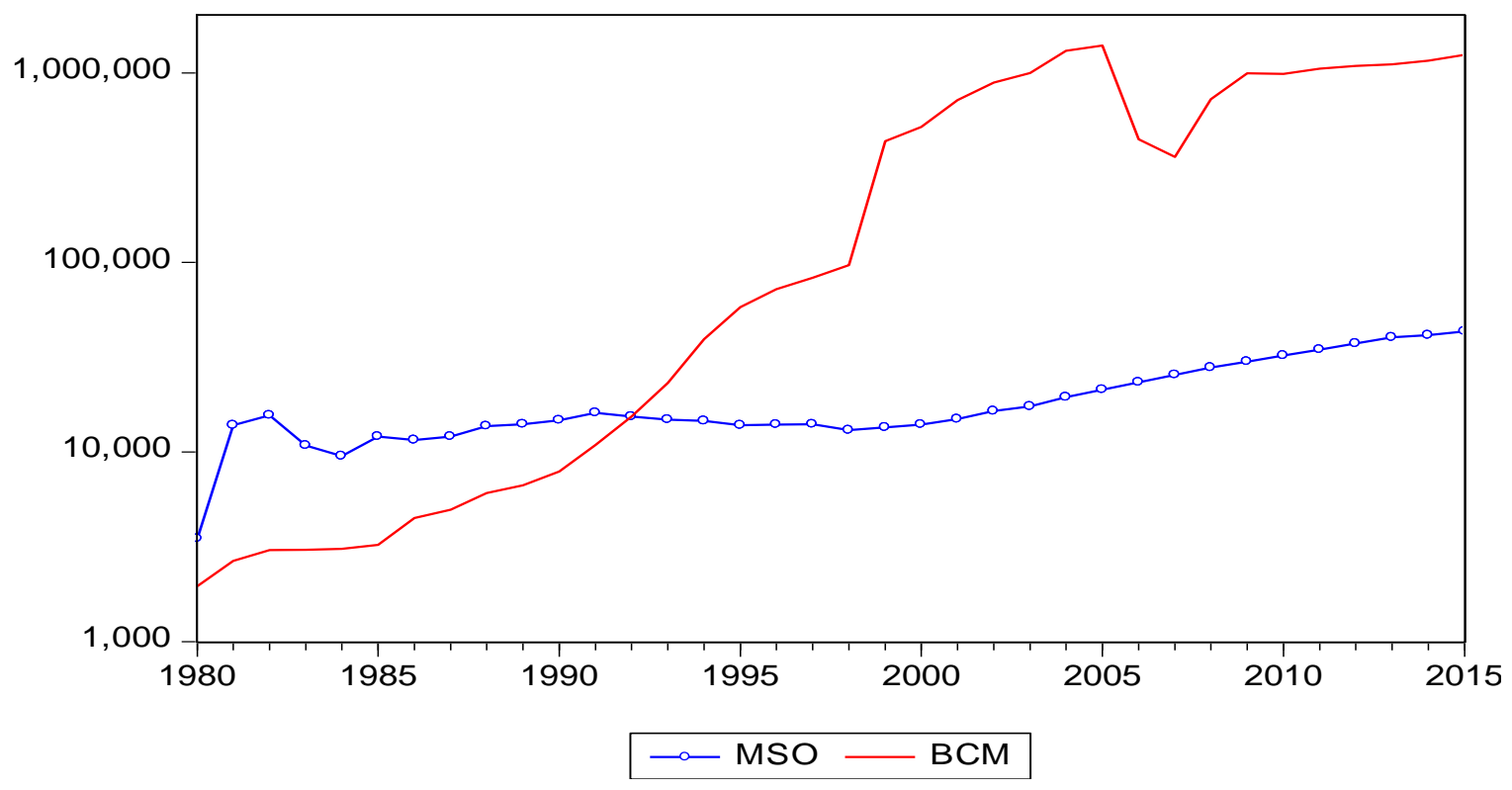

MSO line graph(twig graph) depicts that from 1980 to 1982 the MSO increased, which might be as a result of bank credit increment to the manufacturing sector. But, MSO decline between 1983 and 1984, and it has been swinging upwards, this might also be as a result of the bank credit increase to the manufacturing sector 
Fig.2 Manufacturing Sector Output \& Government Expenditure/Spending

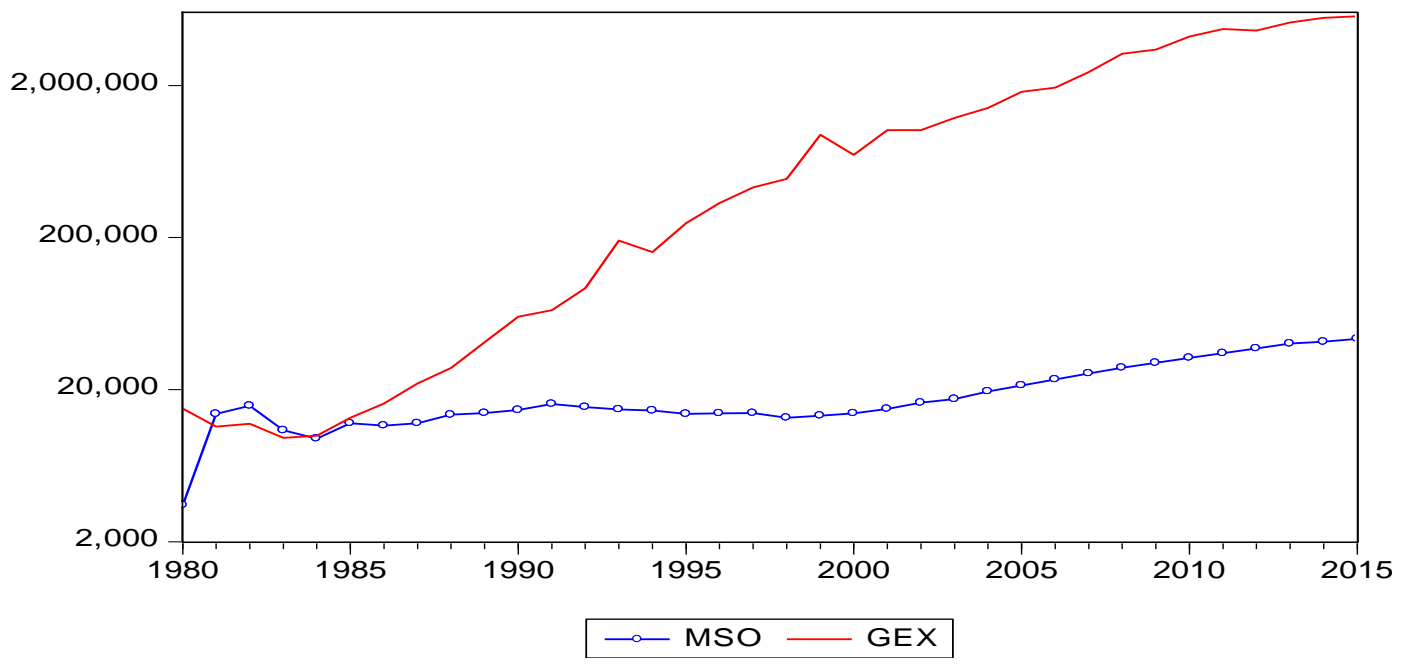

it display that MSO graph(twig line graph) was low from 1980 to 1981, but between 1998 to 2015 it has been experiencing upward increase, despite the fact that it is not in consonant with the increment in government expenditure.

Fig.3 Manufacturing Sector Output \& Gross Capital Formation

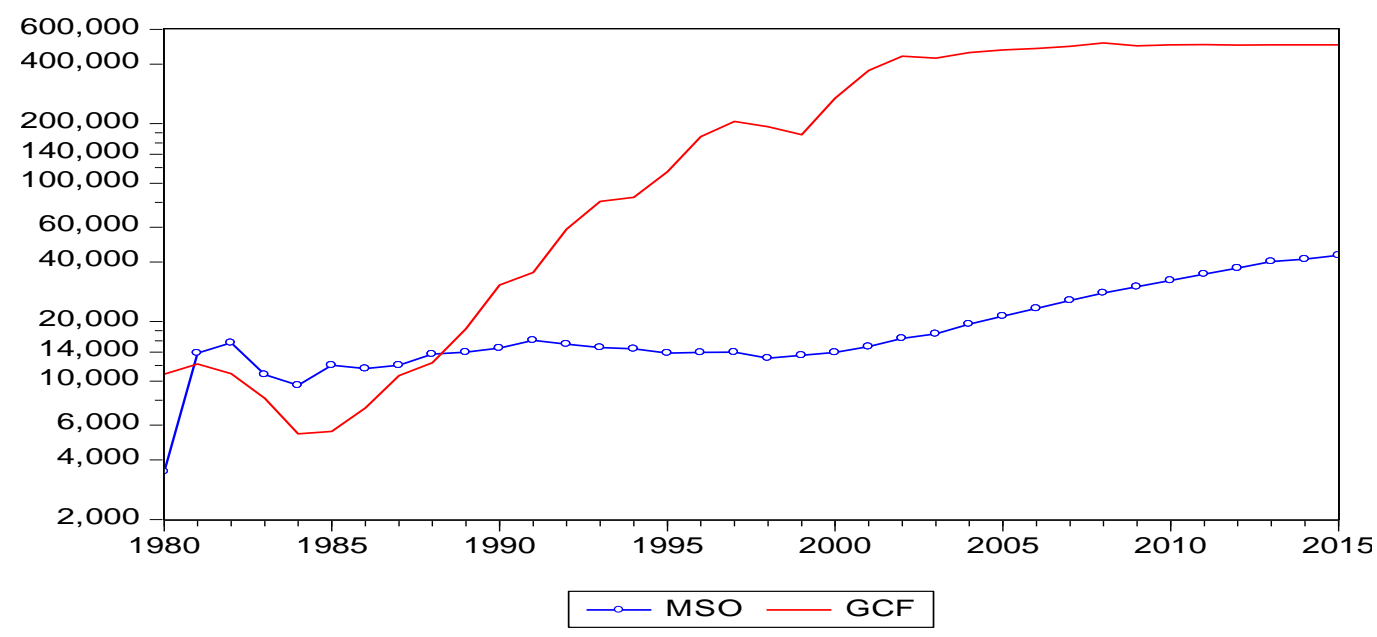

From 1981 to 1987 the MSO was relatively higher than GCF. But it should be noted that MSO might have been influenced by other factors as well. Gross capital formation diagram depicts that it was higher than the MSO, which shows that GCF impacted MSO positively and not negatively from 1988 to 2015.

Fig.4 Manufacturing Sector Output \& Tertiary School Enrolment 
MSO

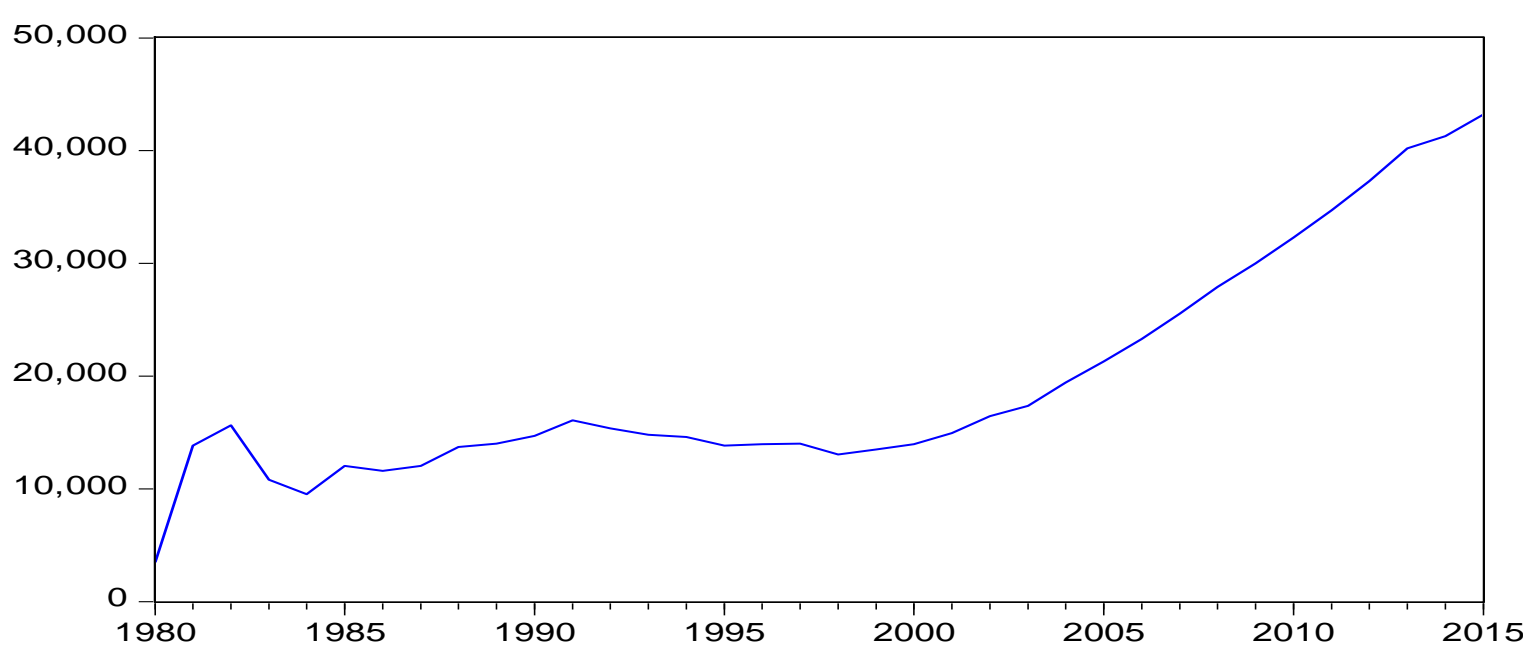

TSE

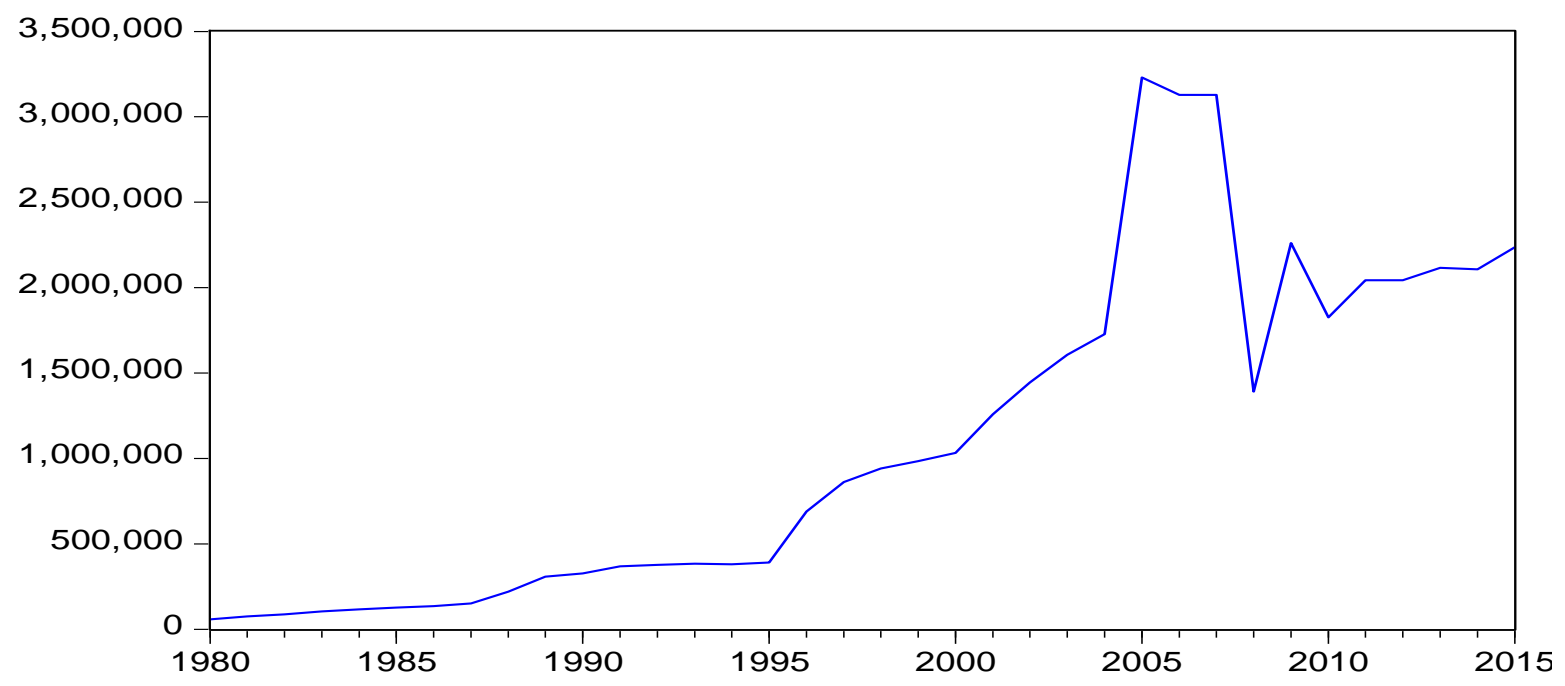

From the graphs above, It depicts that MSO and TSE were apart. Though high level of technical know-how is needed in the manufacturing sector, but the citizens keep chasing the paper certificate rather than the knowledge.

\subsection{Unit Root Test (Stationarity Test)}

In most cases short run test could exhibit spurious result, a stationarity analysis becomes vital. In testing the unit root of the various variables, Augmented Dickey-Fuller (ADF) unit root test is used. The ADF technique used is based on the pattern of the equation presented thus: $\Delta \mathrm{y}_{\mathrm{t}}=\alpha_{0}+\alpha_{1} \mathrm{y}_{\mathrm{t}-1}+\Sigma \alpha_{1} \Delta \mathrm{y}_{\mathrm{i}}+\delta_{\mathrm{t}}+\mathrm{U}_{\mathrm{t}}$ 
Table 4.2: Unit Root Stationarity Test (1980-2015)

\begin{tabular}{|l|l|l|l|l|l|l|}
\hline \multirow{2}{*}{ Variables } & ADF Test & \multicolumn{3}{|c|}{ Critical Values } \\
\cline { 2 - 7 } & & $\begin{array}{l}\text { Critical } \\
\text { Value 1\% }\end{array}$ & $\begin{array}{l}\text { Critical } \\
\text { Value 5\% }\end{array}$ & $\begin{array}{l}\text { Critical } \\
\text { Value 10\% }\end{array}$ & $\begin{array}{l}\text { Order of } \\
\text { Integration }\end{array}$ & P-Value \\
\hline MSO & -6.703681 & -3.639407 & -2.951125 & -2.614300 & $1(1)$ & 0.0000 \\
\hline BCM & -4.906903 & -3.639407 & -2.951125 & -2.614300 & $1(1)$ & 0.0003 \\
\hline GEX & -4.602528 & -3.639407 & -2.951125 & -2.614300 & $1(1)$ & 0.0008 \\
\hline GCF & -3.442866 & -3.639407 & -2.951125 & -2.614300 & $1(1)$ & 0.0162 \\
\hline TSE & -7.661564 & -3.639407 & -2.951125 & -2.614300 & $1(1)$ & 0.0000 \\
\hline
\end{tabular}

Source: Authors' Computed Result from (E-views 9)

The stationarity result in Table 4.2 showed that the variables were stationary at first difference. That is, manufacturing sector output (MSO), bank credit to manufacturers (BCM), government expenditure (GEX), gross capital formation (GCF), and tertiary school enrolment were all stationary at first difference.

\subsection{Co-integration Test}

The general form of co-integration is given by $\mathrm{y}_{\mathrm{t}}=\mu+\Delta_{1} \mathrm{y}_{\mathrm{t}-1}+--+\Delta \mathrm{P} \mathrm{y}_{\mathrm{t}-\mathrm{p}}+\mathrm{U}_{\mathrm{t}}$.

\section{Table 4.3 Test for Co-integration}

Date: 06/15/17 Time: 11:40

Sample (adjusted): 19822015

Included observations: 34 after adjustments

Trend assumption: Linear deterministic trend

Series: MSO BCM GEX GCF TSE

Lags interval (in first differences): 1 to 1

Unrestricted Cointegration Rank Test (Trace)

\begin{tabular}{ccccc}
\hline \hline $\begin{array}{c}\text { Hypothesized } \\
\text { No. of CE(s) }\end{array}$ & Eigenvalue & $\begin{array}{c}\text { Trace } \\
\text { Statistic }\end{array}$ & $\begin{array}{c}0.05 \\
\text { Critical Value }\end{array}$ & Prob.** \\
\hline \hline None ${ }^{*}$ & 0.685516 & 108.4694 & 69.81889 & 0.0000 \\
At most $1 *$ & 0.646606 & 69.13750 & 47.85613 & 0.0002 \\
At most 2* & 0.453580 & 33.77170 & 29.79707 & 0.0165 \\
At most 3 & 0.311345 & 13.22320 & 15.49471 & 0.1069 \\
At most 4 & 0.015777 & 0.540699 & 3.841466 & 0.4621 \\
\hline \hline
\end{tabular}

Trace test point to 3 co integrate eqn(s) at the 0.05 level

* denotes rejection of the hypothesis at the 0.05 level

**MacKinnon-Haug-Michelis (1999) p-values 
Therefore, the Johansen co-integration Test utilizing the value of the Trace Statistic values reveals that there are three(3) co-integrating equations. MSO has a long-run or term relationship with the other variables (i.e., BCM, GEX, GCF and TSE). The result depicts that there are three (3) co-integrating equations which is also part or necessary prerequisite for conducting the ECM.

\section{Table 4.4 Over-parameterized Error Correction Model}

Dependent Variable: D(MSO)

Method: Least Squares

Date: 06/15/17 Time: 12:14

Sample (adjusted): 19842015

Included observations: 32 after adjustments

\begin{tabular}{crccc}
\hline \hline Variable & Coefficient & Std. Error & t-Statistic & Prob. \\
\hline \hline C & 215.4413 & 416.1203 & 0.517738 & 0.6149 \\
D(MSO(-1)) & 0.488408 & 0.290290 & 1.682487 & 0.1206 \\
D(MSO(-2)) & 0.140495 & 0.196868 & 2.713652 & 0.4903 \\
D(MSO(-3)) & 0.192782 & 0.145100 & 1.328622 & 0.2109 \\
D(BCM) & -0.001612 & 0.003483 & -0.462830 & 0.6525 \\
D(BCM(-1)) & 0.000988 & 0.003008 & 2.328421 & 0.7488 \\
D(BCM(-2)) & $3.20 \mathrm{E}-05$ & 0.003085 & 0.010386 & 0.9919 \\
D(BCM(-3)) & 0.001595 & 0.003423 & 0.465962 & 0.6503 \\
D(GEX) & 0.001706 & 0.002838 & 0.601122 & 0.5599 \\
D(GEX(-1)) & -0.000829 & 0.001605 & -0.516625 & 0.6156 \\
D(GEX(-2)) & 0.000797 & 0.001437 & 0.554236 & 0.5905 \\
D(GEX(-3)) & 0.000331 & 0.002284 & 5.144741 & 0.8875 \\
D(GCF) & 0.002492 & 0.013489 & 0.184780 & 0.8568 \\
D(GCF(-1)) & -0.006426 & 0.020427 & -0.314560 & 0.7590 \\
D(GCF(-2)) & 0.007760 & 0.019360 & 0.400813 & 0.6962 \\
D(GCF(-3)) & -0.004581 & 0.021126 & -0.216851 & 0.8323 \\
D(TSE) & 0.000301 & 0.001041 & 0.289004 & 0.7780 \\
D(TSE(-1)) & -0.001061 & 0.002576 & -0.411880 & 0.6883 \\
D(TSE(-2)) & $5.30 E-05$ & 0.001359 & 2.038966 & 0.9696 \\
D(TSE(-3)) & 0.000504 & 0.001230 & 0.409384 & 0.6901 \\
ECM(-1) & -0.257971 & 0.228510 & -1.128924 & 0.2829 \\
\hline \hline R-squared & 0.707731 & Mean dependent var & 1012.603 \\
Adjusted R-squared & 0.176334 & S.D. dependent var & 1209.984 \\
S.E. of regression & 1098.134 & Akaike info criterion & 17.08527 \\
Sum squared resid & 13264873 & Schwarz criterion & 18.04716 \\
Log likelihood & -252.3643 & Hannan-Quinn criter. & 17.40411 \\
F-statistic & 3.331830 & Durbin-Watson stat & 2.221877 \\
Prob(F-statistic) & 0.318822 & & & \\
\hline \hline & & & & \\
\hline
\end{tabular}


Table 4.5 Parsimonious Error Correction Model

Dependent Variable: D(MSO)

Method: Least Squares

Date: 06/15/17 Time: 12:40

Sample (adjusted): 19842015

Included observations: 32 after adjustments

\begin{tabular}{crcrc}
\hline \hline Variable & Coefficient & Std. Error & t-Statistic & Prob. \\
\hline \hline C & 335.6113 & 319.5586 & 1.050234 & 0.3075 \\
D(MSO(-1)) & 0.300183 & 0.162025 & 1.852700 & 0.0804 \\
D(BCM) & 0.000267 & 0.001710 & 0.156234 & 0.8776 \\
D(BCM(-1)) & 0.000271 & 0.001745 & 2.155521 & 0.0381 \\
D(GEX) & 0.001684 & 0.001078 & 1.562274 & 0.1356 \\
D(GEX(-1)) & 0.000305 & 0.001085 & 3.281078 & 0.0519 \\
D(GEX(-2)) & 0.000935 & 0.001021 & 0.915257 & 0.3722 \\
D(GCF(-1)) & 0.006212 & 0.010103 & 0.614842 & 0.5464 \\
D(GCF(-2)) & 0.005294 & 0.010089 & 0.524766 & 0.6061 \\
D(GCF(-3)) & -0.007508 & 0.012529 & -0.599210 & 0.5565 \\
D(TSE) & 0.000376 & 0.000600 & 0.626248 & 0.5390 \\
D(TSE(-1)) & 0.000247 & 0.000839 & 0.294308 & 0.7719 \\
D(TSE(-2) & 0.000370 & 0.000930 & 0.398099 & 0.6952 \\
ECM(-1) & -0.261130 & 0.157897 & -1.653799 & 0.1155 \\
\hline \hline R-squared & 0.607190 & Mean dependent var & 1012.603 \\
Adjusted R-squared & 0.323493 & S.D. dependent var & 1209.984 \\
S.E. of regression & 995.2120 & Akaike info criterion & 16.94342 \\
Sum squared resid & 17828043 & Schwarz criterion & 17.58468 \\
Log likelihood & -257.0948 & Hannan-Quinn criter. & 17.15598 \\
F-statistic & 2.140280 & Durbin-Watson stat & 2.198810 \\
Prob(F-statistic) & 0.067474 & & & \\
\hline \hline
\end{tabular}

The regression result, as analyzed using E-View 9.0 Software, is presented below.

The ECM can be formulated as follows: $\mathrm{MSO}_{\mathrm{t}}=\alpha_{0}+\Sigma \alpha_{1 \mathrm{t}} \mathrm{BCM}_{\mathrm{t}-1}+\sum \alpha_{2 \mathrm{t}} \mathrm{GEX}_{\mathrm{t}-1}+\sum \alpha_{3 \mathrm{t}} \mathrm{GCF}_{\mathrm{t}-1}+\sum \alpha_{4 \mathrm{t}} \mathrm{TSE}_{\mathrm{t}-1}+\delta_{1} \mathrm{ECM}_{\mathrm{t}-1}$ $+\mathrm{U}_{1-\mathrm{t}}$

$\mathrm{MSO}=335.6113+\Delta_{\mathrm{t}-31}(\mathrm{BCM}) 0.000271+\Delta_{\mathrm{t}-1}(\mathrm{GEX}) 0.000305+\Delta_{\mathrm{t}-1}(\mathrm{GCF}) 0.006212+\Delta_{\mathrm{t}-1}(\mathrm{TSE}) 0.000247$

$\mathrm{t}$-test $=(1.050234) \quad(2.155521)$

$\square \cdot \tilde{\square} \tilde{\square} \square 1 \tilde{\square}$

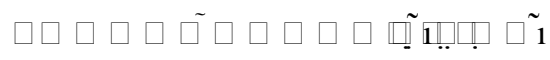

$\tilde{\square} \square \square \square \square \tilde{\tilde{\Pi} \mathbf{1}} \tilde{\square} \square \tilde{\square}$

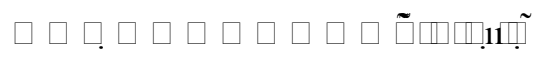


Level of significance $=5 \%$

\section{Evaluation of ECM Results}

The ECM regression result displayed that the $\mathrm{R}^{2}$, which measures the goodness-of-fit, is 0.60 . Therefore, $60 \%$ of the changes or movements in the dependent variable are explained by the changes in the independent/explanatory variables. This leaves only $40 \%$ to the stochastic/disturbance term. The result reveals that the variables taken together are significant at 5\% level with f-test value (2.140280). However, the Durbin-Watson value of 2.198810shows a lesser level of autocorrelation. The ECM is also correctly signed (i.e., negative), while all the variables show the expected apriori signs.

$>$ The bank credit to the manufacturing sector coefficient was positive which conforms to apriori expectation and it was statistically significant at 5\% level (2.155521). This is in agreement with the findings of Tawose (2012), Ogar, Nkamare and Effiong (2014), Akujuobi and Chima (2012), Chinweoke, Egwu and Elizabeth (2015). This implies that more of bank credit is necessary to increase the industrial base of the country.

- The coefficient of government expenditure was positive, which conforms to the apriori expectation. It was also statistically significant at 5\% level of significance (3.281078). This shows that more of government expenditure for infrastructural facilities will boost the manufacturing sector of Nigeria.

- The sign of the gross capital formation is positive which conforms to apriori expectation, but it was not statistically significant. This can be as a result of mis-appropriation of capital funds for the manufacturing sector.

- Tertiary school enrolment conforms to apriori expectation, which depicts that labour is very vital to the development of the manufacturing sector, and government support to education and training of man power is very necessary. However not being significant could be due to citizens pursuing paper qualification instead of the knowledge and technical know-how.

$>$ Causality Relationship

Table 4.6 Pairwise Granger Causality Test Result

Pairwise Granger Causality Tests

Date: 06/15/17 Time: 11:42

Sample: 19802015

Lags: 2

\begin{tabular}{lccc}
\hline \hline Null Hypothesis: & Obs & F-Statistic & Prob. \\
\hline \hline BCM does not Granger Cause MSO & 34 & 3.02124 & 0.0643 \\
MSO does not Granger Cause BCM & & 1.16710 & 0.3255 \\
\hline \hline GEX does not Granger Cause MSO & 34 & 6.60948 & 0.0043 \\
MSO does not Granger Cause GEX & & 0.11260 & 0.8939 \\
\hline \hline GCF does not Granger Cause MSO & 34 & 4.10821 & 0.0269 \\
MSO does not Granger Cause GCF & & 0.40869 & 0.6683 \\
\hline \hline
\end{tabular}

(C) 2019, IJSMS

Page 14 
TSE does not Granger Cause MSO

MSO does not Granger Cause TSE

GEX does not Granger Cause BCM

BCM does not Granger Cause GEX

GCF does not Granger Cause BCM

BCM does not Granger Cause GCF

TSE does not Granger Cause BCM

BCM does not Granger Cause TSE

GCF does not Granger Cause GEX

GEX does not Granger Cause GCF

TSE does not Granger Cause GEX

GEX does not Granger Cause TSE

TSE does not Granger Cause GCF

GCF does not Granger Cause TSE
34

3.40266

0.02671
0.0470

0.9737
34

1.97271

0.1573

$1.26880 \quad 0.2963$

$\begin{array}{lll}34 & 7.85761 & 0.0019\end{array}$

$0.22333 \quad 0.8012$

$\begin{array}{lll}34 & 8.59473 & 0.0012\end{array}$

$17.3754 \quad 1 . \mathrm{E}-05$

$\begin{array}{lll}34 & 7.73027 & 0.0020\end{array}$

$0.11410 \quad 0.8926$

\begin{tabular}{lll}
34 & 9.70151 & 0.0006 \\
& 0.15342 & 0.8585 \\
\hline \multirow{2}{*}{34} & 0.48565 & 0.6202 \\
& 5.66175 & 0.0084
\end{tabular}

Source: Computed Result (E-View 9)

The result of table 4.6 above shows that bank credit to the manufacturing sector (BCM) was found to granger cause manufacturing sector output (MSO), government expenditure (GEX) granger cause manufacturing sector output (MSO), gross capital formation(GCF) granger cause manufacturing sector output (MSO). Tertiary school enrolment (TSE) granger cause manufacturing sector output (MSO), gross capital formation (GCF) granger cause bank credit to the manufacturing sector (BCM), gross capital formation (GCF) granger cause government expenditure (GEX), tertiary school enrolment (TSE) granger cause government expenditure (GEX). This implies that there was a unidirectional causality between bank credit to the manufacturing sector (BCM) and manufacturing sector output (MSO), government expenditure (GEX) and manufacturing sector output (MSO), gross capital formation (GCF) and manufacturing sector output (MSO), tertiary school enrolment (TSE) and manufacturing sector output (MSO). This implies that there is no feedback. But tertiary school enrolment and bank credit to manufacturing sector granger cause each other, which is bi-directional causality, meaning that tertiary school enrolment and bank credit to manufacturing sector has great impact on manufacturing sector output in Nigeria.

\section{Policy Implications}

$>$ Bank loan/credit to the manufacturing sector is needed to the enlargement of the manufacturing sector, and could promote industrialization.

$>$ Bank loan/credit to the manufacturing sector must be adequately supervised by the financial institutions so that the credits are not meandered to other things.

$>$ Beneficiaries of such funds must be tightly followed-up to pay back at the due date, which will reduce the bottle-neck in dispatching the loans.

\subsection{SUMMARY, CONCLUSION AND RECOMMENDATIONS}

\subsection{Summary of Findings}

The research paper examined the influence of credits from bank on the manufacturing sector in Nigeria from 1980 to 2015. However, it has been gifted to make available empirical in rank on the sort of the bond between the 
International Journal of Science and Management Studies (IJSMS)

Volume: 2 Issue: 4
July to August 2019
E-ISSN: 2581-5946

www.ijsmsjournal.org

manufacturing sector output and the self-regulating variables (i.e., credits from bank to the manufacturing sector, expenditure from government, formation of gross capital and tertiary academic enrolment). The falling off consequence exposed that the variables conform to apriori expectations. Credit from bank to the manufacturing sector and expenditure from government were statistically good in the ECM, that is, they put in to the increases in the manufacturing sector. The $\left(\mathrm{R}^{2}\right)$ exhibited zealous link between manufacturing sector output and the explanatory variables. The F-test shows that the variables were statistically okay at $5 \%$ level. Granger causality consequence showed that causal association exists between manufacturing sector output and credit from bank to the manufacturing sector.

\subsection{Conclusion and Recommendations}

The research paper examined the effect of credits on the manufacturing sector in Nigeria 1980 to 2015. The manufacturing sector output increases as the manufacturing sector credit from bank is increasing at an economically favourable figure. The apriori expectation which shows that nonstop proliferate in these variables will force the manufacturing sector to top productivity which will boost Nigeria's gross domestic product. The granger causality displayed that credit spur the manufacturing sector. Therefore, the expenditure on borrowing supposed to be reduced, and related powers that be must claim a sustained force expected at manufacture guaranteed that banks firmly comply with the confidence allowance approved to the manufacturing sector. Businesses or enterprises in Nigeria can now access credits at affordable cost. This will certainly be the forerunner to amplifying output and domestic outcome of Nigeria. Social infrastructure and inductive environment should be provided by government.

\subsection{Contribution to Knowledge}

The lessons has widen the horizon of experience in the question of confirmed correlation between credit from bank to the manufacturing sector and manufacturing sector output as against the negative belief that fill the mind-set of people because of the fee of borrowing from the bank. The research has discovered that econometric procedure can be used to practicalize the evaluation of credits from bank on the manufacturing sector performance.

\section{ACKNOWLEDGEMENT}

I wish to thank my family and IJSMS for the success of this paper. I thank God Almighty the owner of all knowledge for this research work.

\section{REFERENCE}

[1] Adekanye, F. (1986). Elements of Banking in Nigeria. Lagos, F. and A. Publishers.

[2] Ademu, W. A. (2006). The informal Sector and Employment Generation in Nigeria; The Role of Credit and Employment Generation in Nigeria; Selected Papers for the 2006 Annual Conference of the Nigerian Economic Society, in Calabar, August $22^{\text {nd }}$ to $24^{\text {th }}$.

[3] Adeniyi, O. M. (2006). Bank Credit and Economic Development in Nigeria: A Case Study of Deposit Money Banks in Jos, University of Jos Printing Press.

[4] Ajayi, D. D. (2007). Industrial Subcontracting Linkages in the Lagos Region, Nigeria. The Nigerian Journal of Economics and Social Studies (NJESS). 43 (2), Pp. 265-277.

[5] Akinleye, S. O., Akanni, K. A., \& Oladoja, M. A. (2003). An Appraisal of the Agricultural Credit Guarantee Scheme in Nigeria. Department of Agricultural Economics, Olabisi Onabanjo University, Ago Iwoye, Nigeria. 1(1) Pp. 1-14.

[6] Akujuobi, A. B. C. Chima, C. C. (2012). The Production sector Credit and Economic Development of Nigeria, A Cointegration Analysis, IJEMR, November 2012, 2, issue 11.

[7] Allen, D. S. \& Ndikumana (1998). Financial Intermediation and Economic Growth in Southern Africa. Working Paper Series 1998-004, The Federal Reserve Bank of St. Lousi, available on-line: http://research.stlouifed.org/wp/1998/98-004.pdf

[8] Anthony, E. (2010). Agricultural Credit and Economic Growth in Nigeria: An Empirical Analysis, Business and Economics Journal, 20 (10); BEJ-14 
International Journal of Science and Management Studies (IJSMS)

Volume: 2 Issue: 4
July to August 2019
E-ISSN: 2581-5946

www.ijsmsjournal.org

[9] Anyanwu, C. M. (2010). An Overview of Current Banking Sector Reforms and the Real Sector of the Nigerian Economy. CBN Economic and Financial Review. December, 2010.

[10] Aryeetey, E. (1996). Rural Finance in Africa: Institutional Developments and Access for the Poor, In the Proceedings of the Annual World Bank Conference in Development Economics, The World Bank, Washington DC.

[11] Baridam, D. M. (2012). Research Method in Administration Sciences. Port Harcourt, Para-graphic Publishers.

[12] Beck, T. \& Levine R. (2002). Industry Growth and Capital Allocation: Does Having a Market or Bank-Based System Matter? Journal of Financial Economics, 64(2), Pp 147-180.

[13] Beck, T., Levine R. \& Loayza N. (2000). Finance and the Sources of Growth, Journal of Financial Economics 58: 261-310.

[14] Becker, G. S. (1964). Human Capital; a theoretical and empirical analysis with special reference to education, New York, National Bureau of Economic Research.

[15] Bencivenga, V. R. \& Smith, D. D. (1991). Financial Intermediation and Endogenous Growth, Review of Economics Studies, 58, Pp 195209.

[16] Boyreau-Debray, G. (2003). Financial Intermediation and Growth - Chinese Style, Policy Research: Working Paper 3027: The World Bank.

[17] CBN (2009). Bullion on Monetary Policies in Nigeria. Volume 30(2), Published in Nigeria.

[18] CBN (2010). Statistical Bulletin, Abuja, Nigeria.

[19] CBN (2013). Statistical Bulletin, Abuja, Nigeria.

[20] Chinweoke, N., Egwu, C. C. \& Elizabeth, N. C. (2015). Impact of Commercial Banks' Loans and Advances to Agriculture and Manufacturing Sectors on the Economic Growth of Nigeria (1994-2013). International Journal of Arts and Sciences, 08(05), Pp 29-36.

[21] Crowley, J. (2008). Credit Growth in the Middle East, North Africa and Central Asia Region, IMF Working Paper No: 08/184.

[22] De Gregorio, J \& Guidotti P. E. (1995). Financial Development and Economic Growth. World Development, 23(3), Pp 433-448.

[23] Ebi, B. O. (2014). Commercial Banks Credits and Industrial's Sector Growth in Nigeria, Journal of Economics and Sustainable Development, International Institute of Science and Technology Education, USA, 7(4).

[24] Englama, A., Odoko, F. O. \& Nnanna, O. J. (2004). Financial Markets in Nigeria. Abuja: Has Arts Services, Nigeria.

[25] Eze, C. C., Lemehi, J. I., Ugochukwu, V. C., Awulonu, C. O. A. \& Okon, A. X. (2010). Agricultural Financing Policies and Rural Development in Nigeria, The $84^{\text {th }}$ Annual Conference of the Agricultural Economics Society. Edinburgh, $29^{\text {th }}$ to $31^{\text {st }}$ March, 2010.

[26] Goldsmith, R. W. (1969). Financial Structure and Development, New Haves CT, Yale University Press.

[27] Greenwood, J. \& Jovanorich, B. (1990). Financial Development Growth and the Distribution of Income. Journals of Political Economy. 98 , Pp 1076-1107.

[28] Gujarati, D.N. (2004). Basic Econometric, (4th Ed.). The McGraw-Hill Companies. New York.

[29] Ijere, M. O. (1998). Agricultural Credit and Economic Development. In:Ijere MO; Okorie, A (eds), Readings in Agricultural Finance, Longman, Lagos, Pp 4-9.

[30] Jhingan, M. L. (2006). The Economics of Development and Financing ( $3^{\text {rd }}$ ed) Delhi: Virnda Publication (P) Ltd.

[31] Job, A.O. (2002). Basic Features of Nigeria's Manufacturing Sub - Sector. Central Bank of Nigeria (Bullion), Vol. 26, No. 4 (Oct/Dec)

[32] King, R. \& Levine R. (1993). Finance, Entrepreneurship and Growth: Theory and Evidence, Journal of Monetary Economics. 32, pp 513542.

[33] Lucas, R. (1987). On the Mechanics of Economic Development. Journal of Monetary Economics. 22, Pp 2-42.

[34] Malik, A., Teal, F. \& Baptist, S. (2004). The Performance of Nigerian Manufacturing Firms: Report on the Nigerian Manufacturing Enterprises Survey, Centre for the Study of Africa Economies. University of Oxford, Oxford OXI 3UQ, UK.

[35] Mckinnon, R. (1973). Money and Capital in Economic Development, Washington: The Brooking Institute. 
International Journal of Science and Management Studies (IJSMS)

Volume: 2 Issue: 4
July to August 2019
E-ISSN: 2581-5946

www.ijsmsjournal.org

[36] Mike, J. (2010): Banking Sector Reforms and the Manufacturing Sector: The Manufacturers Association of Nigeria Perspective, Central Bank of Nigeria Economic and Financial Review, 46(4), Pp 57-65.

[37] Mishra, P. K., Das, K. B. \& Pradhan, B. B. (2009). Credit Market Development and Economic Growth in India, Middle Eastern Finance and Economics

[38] Nwankwo, O. (2013). Agricultural Financing in Nigeria: An Empirical Study of Nigerian Agricultural Co-operative and Rural Development Bank (NACRDB): 1990-2010. Journal of Management Research, 5(2), Pp 28-44.

[39] Nwaeze, C. \& Ujah, N. I. (2007). Money, Banking and Finance in a Developing World. Aba; Cheedal Global Publishers Limited.

[40] Nwanyanwu, O. J. (2011). An Analysis of Banks' Credit on the Nigerian Economic Growth (1992-2008). JAS Journal of Economics. 4(1).

[41] Nwosa, P. I. \& Oseni, I. O. (2013). The Impact of Banks Loan to SMEs on Manufacturing Output in Nigeria. Journal of Social and Development Sciences. 4(5), Pp 212-217.

[42] Nzotta, S. M. (1990). Money, Banking and Finance: Theory and Practice, Lagos, International Publishing.

[43] Odedekun, M. O. (1998). Financial Intermediation and Economic Growth in Developing Countries. Faculty of Commerce, University of Swaziland, Swaziland.

[44] Ogar, A., Nkamare, S. E. \& Effiong, C. (2014). Commercial Bank Credit and its Contributions on Manufacturing Sector in Nigeria, Research Journal of Finance and Acounting. 5(22).

[45] Ogujiuba, K. K., Ohuche, F. K. \& Adenuga, A. O. (2004). Credit Availability to Small and Medium Scale Enterprises in Nigeria: Importance of New Capital Base for Banks - Background and Issues, AIAE Working Paper.

[46] Olowa, O. W. \& Olowa A. O. (2011). Issues, Problems and Policies in Agricultural Credit: A Review of Agricultural Credit in Nigeria, Bangladesh e-Journal of Sociology. 8(2), July, 2011.

[47] Rajan, R. G. \& Zingales, L. (1998). Financial Dependence and Growth, American Economic Review 88, pp 559- 586.

[48] Rahman. M. W., Luo, J. \& Cheng, E. (2011). Policies and Performance of Agricultural Credit in Bangladesh: What is the influence on Agricultural Production? Africa Journal of Agricultural Research, 6(31), Pp 6440-6452.

[49] Rebelo, S. (1991). Long Run Policy Analysis and Long Run Growth. Journal of Political Economy, University of Chicago Press. 99(3) Pp 500-521.

[50] Romer, M. P. (1986). Increasing Returns and Long-Run Growth, The Journal of Political Economy. 94(5), Pp 1002-1037, University of Chicago.

[51] Schumpeter, J. A. (1934). The Theory of Economic Development. Cambridge Mass, Harvard University Press.

[52] Shaw, E. S. (1973). Financial Deepening in Economic Development, New York: Oxford University Press.

[53] Tawose, J. O. B. (2012). Effects of Bank Credit on Industrial Performance in Nigeria, Internal Business and Management Journal, 4(2) Pp 158-168.

[54] Timsina, N. (2014). Impact of Bank Credit on Economic Growth in Nepal, NRB Working Paper No.22.

[55] Toby, A. J. \& Peterside, D. B. (2014). Analysis of the Role of Banks in Financing the Agricultural and Manufacturing Sectors in Nigeria.

[56] International Journal of Research in Business Management (IJRBM), 2, Issue 2, Feb 2014, Pp 9-22.

[57] Villalpando, M. B. (2015). Bank Credit and Productivity: Evidence from Mexican Firms, Banco de Mexico, Documents de Investigation, Banco de Mexico, Working Paper No. 2015-06. 